\title{
In vitro Cytotoxic, Genotoxic and Antioxidant/Oxidant Effects of Guaiazulene on Human Lymphocytes
}

\author{
Başak Toğar ${ }^{1 *}$ Kübra Çelik $^{2}$ and Hasan Türkez ${ }^{3}$ \\ ${ }^{1}$ Faculty of Science; Department of Biology; Atatürk University; Erzurum - Turkey. ${ }^{2}$ Faculty of Medical; \\ Department of Physiology; Recep Tayyip Erdoğan University; Rize - Turkey. ${ }^{3}$ Faculty of Sciences; Department of \\ Molecular Biology and Genetics; Erzurum Technical University; Erzurum - Turkey
}

\begin{abstract}
The aim of this study was to evaluate for the cytotoxicity, genotoxicity and antioxidant/oxidant activity of GYZ on human peripheral blood lymphocytes (PBLs). Guaiazulene (GYZ) was added into culture tubes at various concentrations $\left(0-400 \mu \mathrm{g} / \mathrm{mL}^{-1}\right)$. Cytotoxicity against the human lymphocytes cultures was examined by lactate dehydrogenase $(\mathrm{LDH})$ release assay. The proliferative response was estimated by 3-(4,5-dimethylthiazol-2-yl)-2,5diphenyl tetrazolium bromide (MTT) assay. Antioxidant/oxidant activity was evaluated by measuring the total oxidant status (TOS) and total antioxidant capacity (TAC) levels. Micronucleus (MN) and chromosomal aberration (CA) tests were used in genotoxicity studies. The results showed that GYZ caused cytotoxicity in the PBLs at high concentrations, but TOS level were not affected, while the level of TAC was significantly increased. GYZ also did not induce chromosomal aberrations when compared to that of the control group. Results this study clearly revealed that GYZ was not genotoxic and also increased the capacity of the antioxidant in the culture of human PBL cells. This report is first report on the impact of GYZ on human PBL cells.
\end{abstract}

Key words: Guaiazulene, cytotoxicity, genotoxicity, antioxidant activity, oxidant status

\section{INTRODUCTION}

Reactive oxygen species (ROS) and antioxidants are involved in all aspects of aerobic life. Antioxidants are substances that may protect the cells against the effects of ROS (Jin et al. 2012). ROS together with other factors are important mediators in many diseases such as neurodegenerative diseases, cardiovascular diseases, inflammation, and arteriosclerosis (Barlak et al. 2011; Mitjavila and Moreno 2012; López-Alarcón and Denicola 2013). Nowadays, synthetic antioxidants such as buthylated hydroxytoluene (BHT), buthylated hydroxyanisole (BHA) and tert-butylhydroquinone (TBHQ) are widely used in the food industry (Naveena et al. 2008). However, potential cancer-inducing properties of these synthetic antioxidants have encouraged the investigation of natural antioxidants derived from plant components (Jin et al. 2012). There is a growing interest in natural substances exhibiting antioxidant properties for human and animal use as specific preventative pharmaceuticals (Goze et al. 2009). Therefore, several studies have been undertaken on the natural compounds contained in plant antioxidants over the past decade. These antioxidant effects are known to depend on natural compounds present in the plants such as flavonoids, alkaloids, coumarins and terpenes (mono-,di-, tri- tetra-, sesqui-, poli-) (Jin et al. 2012; Bubols et al. 2013).

Sesquiterpenes are compounds containing three isoprene units, which is fifteen carbons and twenty-four hydrogens per molecule $\left(\mathrm{C}_{15} \mathrm{H}_{24}\right)$.

*Author for correspondence: basaktogar@gmail.com 
There are more than 10,000 kinds of sesquiterpenes (Davis and Croteau 2000). They have long been investigated for biological activities such as antigenotoxic (Jahangir et al. 2005), anticancer (Afoulous et al. 2013), antimicrobial (Cirić 2012), antifungal (Kundu et al. 2013), anti-inflammatory (Yu et al. 2012) and antioxidant (Shi et al. 2012). Guaiazulene (GYZ), a bicyclic sesquiterpene present in the essential oils of medicinal and aromatic plants (mainly oils of guaiac and chamomile) and has attracted much attention because of its beneficial biological activities (Fiori et al. 2011) Previous reports have indicated that GYZ has antioxidant, antifungal, antimicrobial, anti-inflammatory, anti-spasmodic, anti-ulcer, antitumoral activities and relaxant properties (Higa et al. 1988; Yanagisawa et al. 1990; Andersen, 1999; Tanaka et al. 2000; Guarrera et al. 2001; Fiori et al. 2008; Fiori et al. 2011; Sleha et al. 2012). Although it has been demonstrated to have interesting biological effects, GYZ has been not proven to be biologically effective on PBL cultures.

This work examined the effects of GYZ on the viability of cultured human blood cells (by LDH and MTT assays) and the role of GYZ on antioxidant capacity (by TAC and TOS analysis) and DNA damage (by MN and CA rates) after GYZ-treatment in cultured human blood cells.

\section{MATERIALS AND METHODS}

\section{Cell cultures}

Human peripheral blood cultures were set up according to a slight modification of the protocol described by Evans and O'Riordan (1975). Human blood samples were obtained from five healthy, non-smokings, non-alcoholic, not under drug therapy and with no recent history of exposure to mutagens; females aged 25-30 years. The heparinized blood $\left(0.5 \mathrm{~mL}^{-1}\right)$ was cultured in $6.0 \mathrm{~mL}^{-1}$ of culture medium (PB-MAX ${ }^{\mathrm{TM}}$ Karyotyping Medium Gibco ${ }^{\circledR}$ Spain) with 5.0 $\mathrm{mg} / \mathrm{mL}^{-1}$ of phytohemagglutinin (Sigma Aldrich $\circledast$, Steinheim, Germany). (Geyikoğlu and Türkez 2006). Guaiazulene (Cas: 489-84-9, $\mathrm{C}_{15} \mathrm{H}_{18}$ ) was purchased from Sigma-Aldrich (Steinheim, Germany), dissolved in ethanol $\left(40 \mu \mathrm{L}^{-1}\right)$ and its 0 , $10,25,75,50,100,150,200$ and $400 \mu \mathrm{g} / \mathrm{mL}^{-1}$ were added to the cultures just before the incubation. The concentrations were selected according to Çelik et al. (2014). Mitomycin C (10 $\mu \mathrm{m}$, Sigma-Aldrich $囚$ ) was used as the positive control in the MTT, LDH, MN and CA assays. Ascorbic acid (10 $\mu \mathrm{m}$, Sigma-Aldrich $\left.{ }^{\circledR}\right)$ and hydrogen peroxide $\left(25 \mu \mathrm{m}\right.$, Sigma-Aldrich $\left.{ }^{\circledR}\right)$ were also used as the positive controls in TAC and TOS analysis, respectively.

\section{3-(4,5-dimethylthiazol-2-yl)-2,5 diphenyltetrazolium bromide MTT assay}

The viability of the cells was assessed by measuring the formation of a formazan from MTT spectrophotometrically (MTT cell proliferation kit Cayman Chemical Company ${ }^{\circledR}$, USA). The whole blood samples were seeded in 96-well plates. Cells were incubated at $37^{\circ} \mathrm{C}$ in a humidified $5 \%$ $\mathrm{CO}_{2} / 95 \%$ air mixture and treated with $\mathrm{GYZ}$ at different concentrations for $24 \mathrm{~h}$. Briefly, MTT was added to the cell cultures for $3 \mathrm{~h}$ and formazan crystals formed were dissolved in dimethyl sulfoxide (Sigma-Aldrich $\left.{ }^{\circledR}\right)$. Then the plates were analyzed using Elisa reader (SigmaAldrich, USA) at $570 \mathrm{~nm}$ wavelength (Lewerenz et al. 2003; Wang et al. 2010).

\section{Lactate dehydrogenase (LDH) assay}

LDH activity was measured in the culture medium as an index of cytotoxicity, using an LDH kit (Cayman Chemical®, USA). In brief, $10^{4}-10^{5} \mu \mathrm{L}^{-1}$ cells/well were seeded in 96-well plates and exposed to different concentrations $\left(0-400 \mu \mathrm{g} \mathrm{mL}^{-}\right.$ ${ }^{1}$ ) of GYZ for $24 \mathrm{~h}$. At the end of exposure, 96well plate was centrifuged at $400 \mathrm{~g}$ for $5 \mathrm{~min}$ to settle down the GYZ present in the solution. Then, a $100-\mu \mathrm{L}^{-1}$ supernatant was transferred to a fresh well of 96-well plate that contained $100 \mu \mathrm{L}$ of reaction mixture from the kit and incubated for $30 \mathrm{~min}$ at room temperature. After incubation, the absorbance of solution was measured at $490 \mathrm{~nm}$ using a microplate reader (Elisa reader Bio-Tek ${ }^{\circledR}$, USA). LDH levels in the media versus the cells were quantified and compared with the control values according to the instruction of kit (Hussain et al. 2005).

\section{Micronucleus (MN) assay}

Human lymphocytes stimulated by GYZ and cultured for about $72 \mathrm{~h}$. After $44 \mathrm{~h} \mathrm{GYZ}$ stimulation, cytochalasin B (Sigma; final concentration of $6.0 \mathrm{mg} / \mathrm{mL}^{-1}$ ) was added. Cells were harvested by centrifugation, treated with a hypotonic solution $\left(0.075 \mathrm{M} \mathrm{KCl} / 37.4^{\circ} \mathrm{C}\right)$ The cells were then centrifuged and a solution (methanol + acetic acid) was added three times. 
The resulting cells were re-suspended and dropped onto clean slides. To prepare the slides, 3-5 drops of the fixed cell suspension were dropped on a clean slide and air-dried. The slides were stained with May Grünwald-Giemsa in phosphate buffer (pH 6.8) and scored. MN was scored in 1000 binucleated cells and the frequency of cells with micronuclei was determined (Turkez et al. 2010).

\section{Chromosomal aberration (CA) assay}

CA tests were performed not only to study the cytotoxicity of the material on cells but also to determine the aberrations induced by the particular material on chromosomes of the human lymphocytes cell line. Human lymphocytes were stimulated by GYZ and cultured for about $72 \mathrm{~h}$. Two hours prior to harvesting, $0.1 \mathrm{~mL}^{-1}$ of colchicine $\left(0.2 \mathrm{mg} \mathrm{mL}^{-1}\right.$, Sigma) was added to the culture flask. Cells were harvested by centrifugation, treated with a hypotonic solution $\left(0.075 \mathrm{M} \mathrm{KCl} / 37.4^{\circ} \mathrm{C}\right)$ Again, the cells were then centrifuged and a solution (methanol + acetic acid) was added three times. The resulting cells were re-suspended and dropped onto clean slides. To prepare the slides, 3-5 drops of the fixed cell suspension were dropped on a clean slide and airdried. The slides were stained with Giemsa in phosphate buffer (pH 6.8). For each treatment, 30 well-spread metaphases were analysed to detect the presence of chromosomal aberrations. Criteria to classify the different types of aberrations (chromatid or chromosome gap and chromatid or chromosome break) were in accordance with the recommendation of EHC (Environmental Health Criteria) 46 for environmental monitoring of human populations (IPCS 1985).

\section{TAC and TOS analysis}

The assay is calibrated with hydrogen peroxide and the results are expressed in terms of micromolar hydrogen peroxide equivalent per liter ( $\mu$ mol $\mathrm{H}_{2} \mathrm{O}_{2}$ Equiv. $\mathrm{L}^{-1}$ ) (Erel 2004). The automated TAC and TOS assays were carried out by commercially available kits (Rel Assay Diagnostics ${ }^{\circledR}$, Gaziantep, Turkey) on plasma samples of GYZ treated cultures for $2 \mathrm{~h}$.

\section{Statistical analysis}

Statistical analysis was performed using SPSS software (version 13.0, SPSS, Chicago, IL, USA). The Duncan's was used to determine whether any treatment significantly differed from the controls or each other. Statistical decisions were made with a significance level of 0.05 .

\section{RESULTS}

Here, the cytotoxicity was determined using a colorimetric method with the MTT assay and an enzymatic method using LDH assay. The effects of GYZ (10- $\left.400 \mu \mathrm{g} / \mathrm{mL}^{-1}\right)$ on cell growth after 24 $\mathrm{h}$ are shown in Figure1. MTT assay demonstrated that GYZ significantly suppressed the proliferation of PBL cells at high concentrations. Cell numbers clearly reduced compared to the control group.

The cytotoxic effects of different concentrations of GYZ on PBL cells at $24 \mathrm{~h}$ are represented in Figure 2. Evidently, 150, 200 and $400 \mu \mathrm{g} / \mathrm{mL}^{-1}$ concentrations of GYZ increased the release of LDH enzyme.

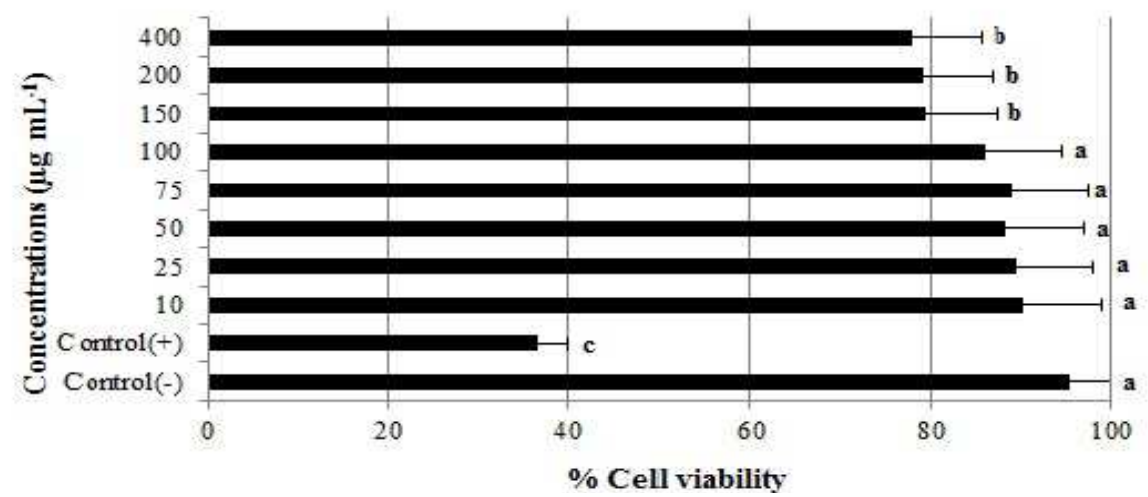

Figure 1 - Effect of GYZ on cell viability under different concentrations on lymphocytes cells using the MTT assay.

Each individual whole blood culture without GYZ was studied as a negative control group (Control-). Different superscript letters in the same column indicate significant differences $(\mathrm{P}<0.05)$. 


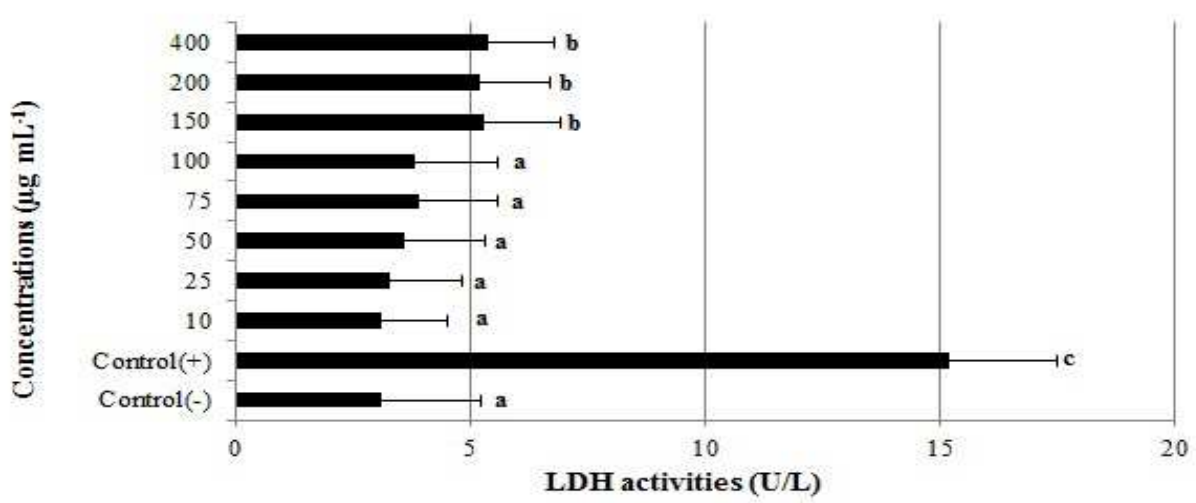

Figure 2 - The effects of GYZ on lactate dehydrogenase (LDH) levels in human peripheral blood lymphocytes cells. The abbreviations are as in Figure 1.

The serum total antioxidant capacity (TAC) and the total oxidant status (TOS) were evaluated by using an automated colorimetric measurement method. As shown from the results presented in Table 1, two concentrations of GYZ (25 and 50 $\mu \mathrm{g} / \mathrm{mL}^{-1}$ ) resulted a significant increase of TAC levels on human lymphocytes cells compared with the controls. On the other hand, GYZ did not change the TOS levels in cultured lymphocytes at all the concentrations.

The effects of GYZ on the number MN in human lymphocytes cultures are shown in Figure 3. Compared to negative-control group, Mitomycin $\mathrm{C}\left(10^{-7} \mathrm{M}\right)$ caused considerable increases of $\mathrm{MN}$ frequencies. GYZ at all applied concentrations $\left(10-400 \mu \mathrm{g} / \mathrm{mL}^{-1}\right)$ did not indicate significant differences in the number of MN compared with the control groups.

The observed CA rate of control and experimental groups are shown in Figure 4. Compared to negative-control group, Mitomycin $\mathrm{C}\left(10^{-7} \mathrm{M}\right)$ caused considerable increases of $\mathrm{CA}$ frequencies.
Results indicated that different concentrations of GYZ did not change the rate of CAs when compared with the control values.

Table 1 - The levels of total antioxidant capacity (TAC) and total oxidant status (TOS) in human peripheral blood lymphocytes cultures treated with GYZ for $24 \mathrm{~h}$.

\begin{tabular}{|c|c|c|}
\hline \multicolumn{3}{|c|}{ Parameters } \\
\hline $\begin{array}{l}\text { Concentrations } \\
\left(\mu \mathrm{g} / \mathrm{mL}^{-1}\right)\end{array}$ & $\begin{array}{c}\text { TAC (Trolox Equiv. } \\
\text { / } \text { mmol L }^{-1} \text { ) }\end{array}$ & $\begin{array}{c}\text { TOS }\left(\mathrm{H}_{2} \mathrm{O}_{2}\right. \\
\left.\text { Equiv. } / \mu \mathrm{mol}^{-1}\right)\end{array}$ \\
\hline Control (-) & $6.24 \pm 0.71^{\mathrm{b}}$ & $11.58 \pm 1,38^{\mathrm{a}}$ \\
\hline Control(+) & $12.46 \pm 1.49^{d}$ & $39.14 \pm 4.59^{c}$ \\
\hline 10 & $6.23 \pm 0.74^{b}$ & $11.61 \pm 1.39^{\mathrm{a}}$ \\
\hline 25 & $9.12 \pm 0.91^{\mathrm{c}}$ & $11.68 \pm 1.40^{\mathrm{a}}$ \\
\hline 50 & $9.32 \pm 0.93^{\mathrm{c}}$ & $11.72 \pm 1.41^{\mathrm{a}}$ \\
\hline 75 & $6.44 \pm 0.76^{\mathrm{b}}$ & $11.69 \pm 1.38^{\mathrm{a}}$ \\
\hline 100 & $6.38 \pm 0.68^{b}$ & $11.73 \pm 1.42^{\mathrm{a}}$ \\
\hline 150 & $6.21 \pm 0.66^{\mathrm{b}}$ & $11.84 \pm 1.39^{\mathrm{a}}$ \\
\hline 200 & $5.56 \pm 0.63^{\mathrm{a}}$ & $11.89 \pm 1.43^{\mathrm{a}}$ \\
\hline 400 & $5.23 \pm 0.57^{\mathrm{a}}$ & $12.13 \pm 1.45^{\mathrm{b}}$ \\
\hline
\end{tabular}

Ascorbic acid $(10 \mu \mathrm{m})$ and hydrogen peroxide $(25 \mu \mathrm{m})$ were also used as the positive controls in TAC and TOS analysis, respectively. Different superscript letters in the same column indicate significant differences $(\mathrm{P}<0.05)$.

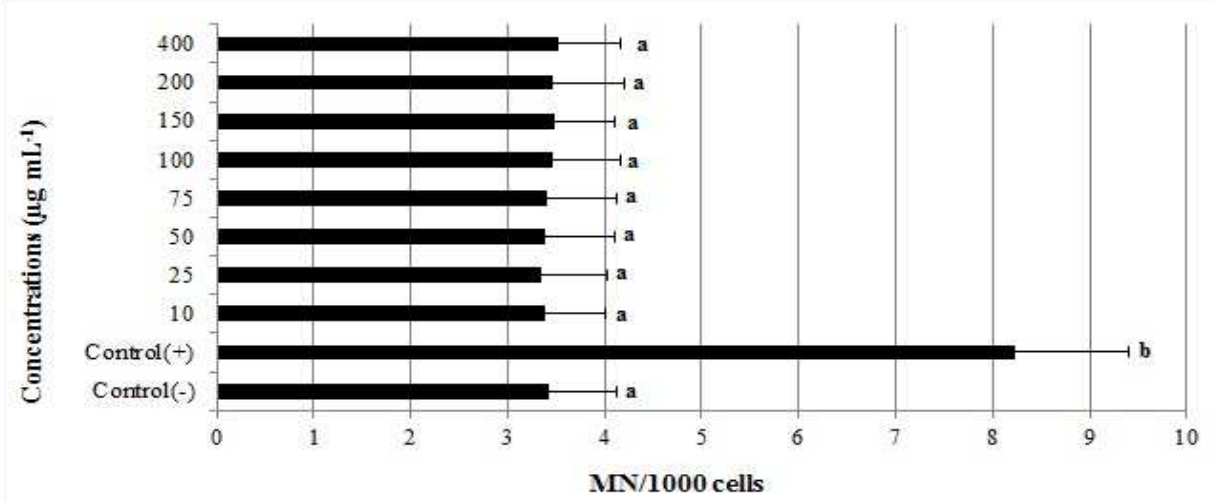

Figure 3 - The rate of micronucleus (MNs) in cultured human peripheral blood lymphocytes exposed to different concentrations of GYZ. The abbreviations are as in Figure 1. 


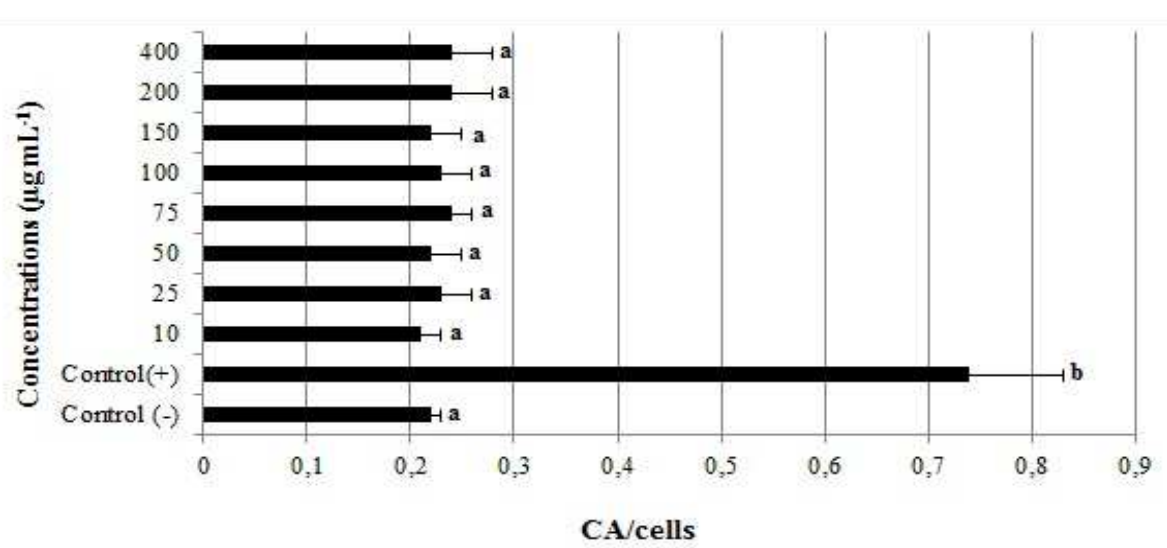

Figure 4 - The rate of chromosomal aberrations (CAs) in cultured human peripheral blood lymphocytes exposed to different concentrations of GYZ. The abbreviations are as in Figure 1.

\section{DISCUSSION}

In the current study, PBLs were treated with different concentrations of GYZ. MTT and LDH assays were used to examine the cytotoxicity effect of GYZ in vitro. MTT assay is a colorimetric method for determining the number of viable cells in proliferation. According to results of MTT analysis, the lower concentrations of the GYZ $\left(10-100 \mu \mathrm{g} / \mathrm{mL}^{-1}\right)$ had no effect in any of the parameters assessed (Fig.1). The highest doses $\left(150,200\right.$ and $\left.400 \mu \mathrm{g} / \mathrm{mL}^{-1}\right)$ of GYZ were cytotoxic for the PBL cells. Lactate dehydrogenase (LDH) is a stable cytosolic enzyme released upon membrane damage in necrotic cells. LDH released into the medium provides an index of cell death and membrane permeability to $\mathrm{LDH}$ and an increase in $\mathrm{LDH}$ activity in the medium occurs as a result of cell membrane fragmentation and enzyme leakage (Yokogawa et al. 2004). According to results of LDH analysis, the highest doses $(150,200$ and $400 \mu \mathrm{g} / \mathrm{mL}$ ) of GYZ resulted increases in the LDH levels compared with the controls (Fig. 2). These results were in agreement with the previous studies, which have reported that GYZ and azulene derivates could exhibit cytotoxic effects on cell lines such as human gingival fibroblast (HGF), pulp cell (HPC), periodontal ligament fibroblast (HPLF) and human tumor cell lines, including submandibular gland carcinoma (HSG), oral squamous cell carcinoma (HSC-2, HSC-3), promyelocytic leukemia (HL-60) (Wakabayashi et al. 2003; Fiori et al. 2011).
The antioxidant/oxidant effects of GYZ have not been investigated on PBL cells. For assessing the antioxidant/oxidant effects of GYZ, total antioxidant capacity (TAC) and total oxidant status (TOS) assays were performed in this study. The level of TAC increased after treatment by GYZ (25 and $50 \mu \mathrm{g} / \mathrm{mL}$ ) compared to control group (Table 1). Similar to these findings, previous studies showed that GYZ inhibited the rat hepatic microsomal membrane peroxidation in vitro (Kourounakis et al. 1997a; Dovolou et al. 2011). In vitro and in vivo studies on the effect of GYZ on rat hepatic cytochrome P450 (CYP) showed that GYZ inhibited CYP1A2 activity (Kourounakis et al. 1997b). Rekka et al. (2002) reported that GYZ considerably inhibited the lipoxygenase activity in rat hepatic microsomal membrane lipids, applying the 2-thiobarbituric acid test. Pratsinis and Haroutounian (2002) demonstrated that 3-vinylguaiazulene (a guaiazulene derivate) had antioxidant properties assayed by 2,2-diphenly-1-picrylhydrazly (DPPH). GYZ applications at all the tested concentrations did not show any significant increases of TOS levels in both the cultures.

Many studies have demonstrated the in vitro or in vivo genotoxicity of several sesquiterpenes but not GYZ in different cell types. This study evaluated the genetic effect of GYZ on human lymphocytes culture using by micronuclei (MN) and chromosomal aberration (CA) assays. The findings showed that GYZ was neither cytotoxic nor genotoxic in vitro. Similar to these findings, Al-Zubairi et al. (2010) reported that zerumbon (a sesquiterpene phytochemical from a type of edible 
ginger) did not induce genotoxicity in the cultured human peripheral blood lymphocytes. Di Sotto et al. (2010) reported that beta-caryophyllene exhibited antigenotoxic activity in human PBL cells against the toxicity of ethyl methanesulfonate (EMS) and colcemid (COL). On the other hand, Gil da Costa et al. (2012) found that ptaquiloside (a norsesquiterpene) was genotoxic in the cultured human lymphocytes by using sister chromatid exchange (SCE) test. Besides, gossypol was also genotoxic in human lymphocyte cells by using SCE (Best and McKenzie 1988). These divergent results suggested the relevance of the chemical structure in the biological effect of sesquiterpenes and indicated the importance of using various test models to reach a valid conclusion.

Consequently, GYZ could be used as a suggested natural antioxidant for therapeutic, pharmaceutical and many health care products and solutions.

\section{ACKNOWLEDGMENTS}

The authors are grateful to all volunteers for the blood samples.

\section{REFERENCES}

Afoulous S, Ferhout H, Raoelison EG, Valentin A, Moukarzel B, Couderc F, et al. Chemical composition and anticancer, antiinflammatory, antioxidant and antimalarial activities of leaves essential oil of Cedrelopsis grevei. Food Chem Toxicol. 2013; 56: 352-362.

Al-Zubairi AS, Abdul AB, Syam MM. Evaluation of the genotoxicity of zerumbone in cultured human peripheral blood lymphocytes. Toxicol In Vitro. 2010; 24: 707-712.

Andersen FA. Thirty-seventh report of the cosmetic ingredient review expert panel on the safety assessment of cosmetic ingredients. Int $J$ Toxicol. 1999; 18: 59.

Barlak Y, Değer O, Colak M, Karataylı SC, Bozdayı AM, Yücesan F. Effect of Turkish propolis extracts on proteome of prostate cancer cell line. Proteome Sci. 2011; 9: 74.

Best RG, McKenzie WH. Variable Sister-chromatid exchange response in human lymphocytes exposed in vitro to gossypol acetic acid. Mutat Res. 1988; 206: 227-233.

Bubols GB, Vianna Dda R, Medina-Remon A, von Poser G, Lamuela-Raventos RM, Eifler-Lima VL, et al. The antioxidant activity of coumarins and flavonoids. Mini Rev Med Chem. 2013; 13: 318-334.
Cirić A, Karioti A, Koukoulitsa C, Soković M, Skaltsa H. Sesquiterpene lactones from Centaurea zuccariniana and their antimicrobial activity. Chem Biodivers. 2012; 9: 2843-2853.

Çelik K, Toğar B, Turkez H, Taşpınar N. In vitro cytotoxic, genotoxic and oxidative effects of acyclic sesquiterpene farnesene. Turk J Biol. 2014; 38: 253 259.

Davis ME, Croteau R. Cyclization enzymes in the biosynthesis of monoterpenes, sesquiterpenes, and diterpenes topics in current. Top Curr Chem. 2000; 209: 54-92.

Di Sotto A, Mazzanti G, Carbone F, Hrelia P, Maffei F. Inhibition by beta-caryophyllene of ethyl methanesulfonate-induced clastogenicity in cultured human lymphocytes. Mutat Res. 2010; 699: 23-28.

Dovolou E, Clemente M, Amiridis GS, Messinis IE, Kallitsaris A, Gutierrez-Adan A, et al. Effects of guaiazulene on in vitro bovine embryo production and on mRNA transcripts related to embryo quality. Reprod Domest Anim. 2011; 46: 862-869.

Erel O. A novel automated direct measurement method for total antioxidant capacity using a new generation, more stable ABTS radical cation. Clin Biochem. 2004; 37: 277-285.

Evans HJ, O'Riordan ML. Human peripheral blood lymphocytes for the analysis of chromosome aberrations in mutagen tests. Mutat Res. 1975; 31: 135-148.

Fiori J, Teti G, Gotti R, Mazzotti G, Falcon M. Cytotoxic activity of guaiazulene on gingival fibroblasts andthe influence of light exposure on guaiazulene-induced cell death. Toxicol In Vitro. 2011; 25: 64-72.

Fiori J, Gotti R, Albini A, Cavrini V. Study on the photostability of guaiazulene by high-performance liquid chromatography/mass spectrometry and gas chromatography/mass spectrometry. Rapid Commun Mass Spectrom. 2008; 22: 2698-2706.

Geyikoğlu F, Turkez H. Protective effect of sodium selenite against the genotoxicity of aflatoxin B-1 in human whole blood cultures. Braz Arch Biol Technol. 2006; 49: 393-8.

Gil da Costa RM, Oliveira PA, Bastos MM, Lopes CC, Lopes C. Ptaquiloside-induced early-stage urothelial lesions show increased cell proliferation and intact $\beta$ catenin and e-cadherin expression. Environ Toxicol. 2014; 29: 763-769

Goze İ, Alim A, Sihoglu A, Sökmen M, Sevgi K, Tepe B. Screening of the antioxidant activity of essential oil and various extracts of Origanum rotundifolium Boiss. from Turkey. J Med Plant Res. 2009; 3: 24654.

Guarrera M, Turbino L, Rebora A. The antiinflammatory activity of azulene. J Eur Acad Dermatol Venereol. 2001; 15: 486-487. 
Higa T, Sakemi S. Guaiazulene derivatives and their methods of use. US Patent No. US 4755529 A. 1988; 5-7.

Hussain SM, Hess KL, Gearhart JM, Geiss KT, Schlager JJ. In vitro toxicity of nanoparticles in BRL 3A rat liver cells. Toxicol In Vitro. 2005; 19: 975983.

IPCS. (International Program on Chemical Safety), Environmental Health Criteria 46. Guidelines for the Study of Genetic Effects in Human Populations. WHO, Geneva. 45-1985; 54 pp.

Jahangir T, Khan TH, Prasad L, Sultana S. Alleviation of free radical mediated oxidative and genotoxic effects of cadmium by farnesol in Swiss albino mice. Redox Rep. 2005; 10:303-310.

Jin L, Zhang Y, Yan L, Guo Y, Niu L. Phenolic compounds and antioxidant activity of bulb extracts of six Lilium species native to China. Molecules. 2012; 17: 9361-9378.

Kourounakis AP, Rekka EA, Kourounakis PN. Antioxidant activity of guaiazulene and protection against paracetamol hepatotoxicity in rats. J Pharm Pharmacol. 1997a; 49: 938-942.

Kourounakis AP, Rekka EA, Kourounakis PN. Effect of guaiazulene on some cytochrome P450 activities. Implication in the metabolic activation and hepatotoxicity of paracetamol. Arch Pharm (Weinheim). 1997b; 330: 7-11.

Kundu A, Saha S, Walia S, Shakil NA, Kumar J, Annapurna K. Cadinene sesquiterpenes from Eupatorium adenophorum and their antifungal activity. J Environ Sci Health B. 2013; 48: 516-522.

Lewerenz V, Hanelt S, Nastevska C, El-Bahay C, Rouhrdanz E, Kahl R. Antioxidants protect primary rat hepatocyte cultures against acetaminopheninduced DNA strand breaks but not against acetaminophen-induced cytotoxicity. Toxicol. 2003; 191: 179-118.

López-Alarcón C, Denicola A. Evaluating the antioxidant capacity of natural products: a review on chemical and cellular-based assays. Anal Chim Acta. 2013; 763: 1-10.

Mitjavila MT, Moreno JJ. The effects of polyphenols on oxidative stress and the arachidonic acid cascade: Implications for the prevention/treatment of high prevalence diseases. Biochem Pharmacol. 2012; 84: 1113-1122.

Naveena BM, Sen AR, Kingsly RP, Singh DB, Kondaiah N. Antioxidant activity of pomegranate rind powder extract in cooked chicken patties. Int $J$ Food Sci \& Technology. 2008; 43:1807-1812.
Pratsinis H, Haroutounian SA. Synthesis and antioxidant activity of 3-substituted guaiazulene derivatives. Nat Prod Lett. 2002; 16: 201-205.

Rekka E, Chrysselis M, Siskou I, Kourounakis A. Synthesis of new azulene derivatives and study of their effect on lipid peroxidation and lipoxygenase activity. Chem Pharm Bull (Tokyo). 2002; 50: 904907.

Shi Q, Fu J, Ge D, He Y, Ran J, Liu Z, et al. Huperzine A ameliorates cognitive deficits and oxidative stress in the hippocampus of rats exposed to acute hypobaric hypoxia. Neurochem Res. 2012; 37: 20422052.

Tanaka M, Yamaki F, Saitoh M, Nakazawa T, Tanaka $\mathrm{H}$, Noguchi $\mathrm{K}$, et al. Relaxant action of azulenecarboxamidine derivative N1, N1-dimethyl-N2-(2pyridilmethyl)-5-isopropyl-3,8-dimethylazulene-1carboxamidine (HNS-32) in pig coronary artery. Pharm Pharmacol Commun. 2000; 6: 397-404.

Turkez H, Geyikoglu F, Aslan A, Karagöz Y, Turkez O, Anar M. Antimutagenic effects of lichen Pseudovernia furfuracea (L.) Zoph. extracts against the mutagenicity of aflatoxin B1 in vitro. Toxicol Ind Health. 2010; 26: 625-631.

Wakabayashi H, Nishishiro M, Arikawa S, Hashimoto $\mathrm{K}$, Kikuchi H, Nishikawa H, et al. Cytotoxic activity of azulenes against human oral tumor cell lines. Anticancer Res. 2003; 23: 4747-4756.

Wang T, Jiang A, Zhang J, Jing F. Apoptosis induction by E2F decoy DNA of the prostate cancer cell line. Braz Arch Biol Technol. 2010; 53: 327-334.

Yanagisawa T, Kosakai K, Tomiyama T, Yasunami M, Takase K. Studies on anti-ulcer agents. II. Synthesis and antiulcer activities of 6-isopropylazulene-1sodium sulfonate derivatives. Chem Pharm Bull (Tokyo). 1990; 38: 3355-3358.

Yokogawa K, Watanabe M, Takeshita H, Nomura M, Mano Y, Miyamoto K. Serum aminotransferase activity as a predictor of clearance of drugs metabolized by CYP isoforms in rats with acute hepatic failure induced by carbon tetrachloride. Int $J$ Pharm. 2004; 269: 479-489.

Yu WY, Kan WJ, Yu PX, Li MM, Song JS, Zhao F. Anti-inflammatory effect and mechanism of artemisinin and dihydroartemisinin. Zhongguo Zhong Yao Za Zhi. 2012; 37:2618-2621.

Received: February 03, 2014; Accepted: June 26, 2014. 